\title{
DOI 10.26886/2520-7474.6(44)2020.7
}

UDC 72.04:75(477.86-25)

STYLISTIC FEATURES AND IDEOLOGICAL CODES OF MODERN URBAN MURALS: THE CASE OF IVANO-FRANKIVSK CITY

\section{S. Chuchuk, Postgraduate student}

https://orcid.org/0000-0002-9484-4196

e-mail: solomia2903@gmail.com

Vasyl Stefanyk Precarpathian National University, Ukraine, Ivano-Frankivsk

The article presents the analysis of artistic murals in the environment of modern cities, drawing on examples from Ivano-Frankivsk city, author's reflections as well as on published sources. Particular attention is paid to stylistic features and ideological codes of the wall paintings. The paper deals with traditional, conceptual and religiously-themed murals, illuminates issues of their correlations with urban spaces, highlights main modern styles and artistic practices used in the process of mural design. The research reported here contributes to the urban studies and understanding of effective forms of art integration into environments of modern cities.

Keywords: mural, urban environment, artistic practices, wall painting, visual space.

Introduction. The visual environment of modern cities is a direct projection of socio-cultural processes of their population, a means of translating social ideological codes. An important role in these processes is given to artistic practices. A. lefimova, while researching current artistic trends in the urban spaces of Western Ukraine, states that contemporary art «primarily has a mission to visually accentuate space, give it a certain symbolic and cultural meaning, as well as to convey to society an important problem, or actualize historical and collective memory» [1, p. 286]. Thus, 
the phenomenon of art murals existence in the city environment lies in their dualistic nature: the correlation of the concepts of "aesthetics" and "ethics". Therefore the study of their stylistic features and ideological meanings is of particular interest and relevance.

Research publications. Some issues of modern muralism in Ukraine were studied by E. Molyar [4;7]; artistic practices in the cities of Western Ukraine were covered by $\mathrm{N}$. Babii [5]; modern monumental art practices in Western Ukraine were studied by A. lefimova [1]; murals as a means of social communication were considered by researchers $\mathrm{O}$. Kolisnyk and $\mathrm{N}$. Ponomarova [2].

The aim of the article is to analyze various murals in the environment of Ivano-Frankivsk and to determine their stylistic features and embedded ideological codes.

The main material. There is no unanimous opinion among experts on the interpretation of the term "mural", so, after analyzing different views on this issue, we define the mural as a sizeable wall painting in an urban environment, that can be characterized as narrative and interactive, with an opportunity to illustrate the existential foundations of creative minorities. «...The main stylistic tendencies of the mural art were borrowed from Europe and America after the collapse of the USSR. In addition to domestic highly professional artists, foreign artists from abroad were invited to create murals. The world experience of muralism has left its mark on the domestic mural art, but at the same time it has not lost its national motives and authenticity" [2, p. 68].

For more detailed analysis of murals in the environment of IvanoFrankivsk, we allocate categories of their figurative and ideological direction: traditional, conceptual, religious-themed.

Traditional murals reflect the largest layer of creative works of IvanoFrankivsk visual environment. The specifics of their creation, mostly, involve 
the fact of ordering a work of art by the city authorities, private organizations or patrons. From this follows a certain ideological limitations, censorship, generated by focusing on the aesthetic expectations of the general public. Traditional murals are devoid of ambiguity of visual codes, very often perform only a decorative function, or carry trivial messages of a general nature, but their impact on the visual space of the city remains strong and is difficult to overestimate. While being extensive, color-active optical accents in the architectural setting, they are able to radically transform the artistic and spatial environment.

For example, consider the murals of the artist Yu. Pitchuk, who has established himself in the visual environment of Ivano-Frankivsk in a number of works. His artistic and stylistic language is subjected to certain schemes, the color palette is limited. The author is inherent in the use of local turquoise, purple and orange tones as well as figurative, often ethnically oriented, images, exploitation of the rigid graphic line and style of pop art.

Special mention should be made of the work of the KickitArtStudio team, whose murals border with the form of post-graffiti, have a distinctive style and are recognizable by the means of expression. The group's works are characterized by surreal plots, multi-figure images, specific stylization and soft graphic style. For example, a mural on the wall of the children's city hospital at 44, Chornovola str. (which can be easily attributed to both mural and post-graffiti) (Fig.1) or a mural in purple that combines different styles of wall painting, created in collaboration with the public organization "Try Dvory" as part of the urban festival "City Scanning Session" at 5, Franko str. in Ivano-Frankivsk (Fig.2).

The murals of the artist Roman Bonchuk - a painting with the image of Ivan Franko at 19, Beljvederska str., accompanied by a text from his poem "I am the son of the people going up" (Fig. 3) and a portrait mural of Roman 
Guryk - Ivano-Frankivsk hero of the "Nebesna Sotnia" at 83, Mazepy str. (Fig. 4) caused a lot of controversial discussions among both the people of the city

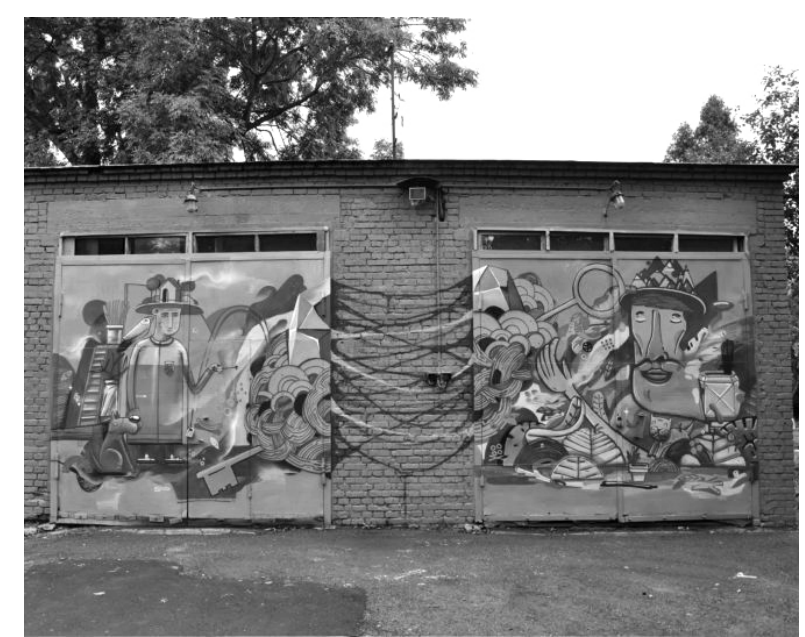

Fig.1. Mural at 44, Chornovola str.

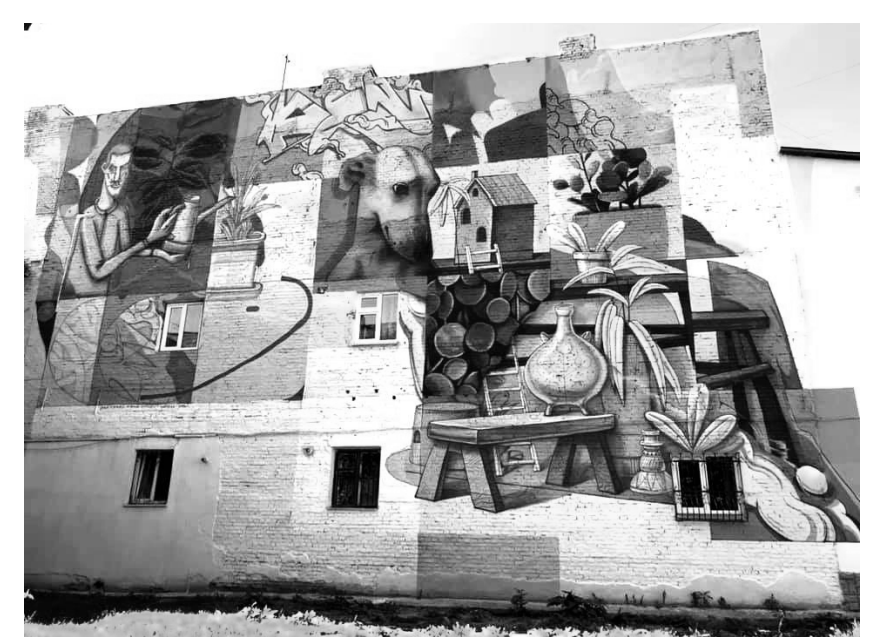

Fig.2. Mural at 5, Franko str.

and the artistic elite. Both the technical qualities of the work and their ethical implication were questioned. A. Zvizhynskyi, an artist and art critic from Ivano-Frankivsk, commented on this: "The artist has long been speculating on historical and heroic themes, often bringing the essence of the conversation to absurdity. Negligent (or incompetent) technique of execution is presented as own stylistics, or resorts to formal explains: supposedly, the size matters. Author combines patriotism with business (how else will he explain the presence of a huge logo of a local construction organization on the portrait of R. Guryk?)"[3].

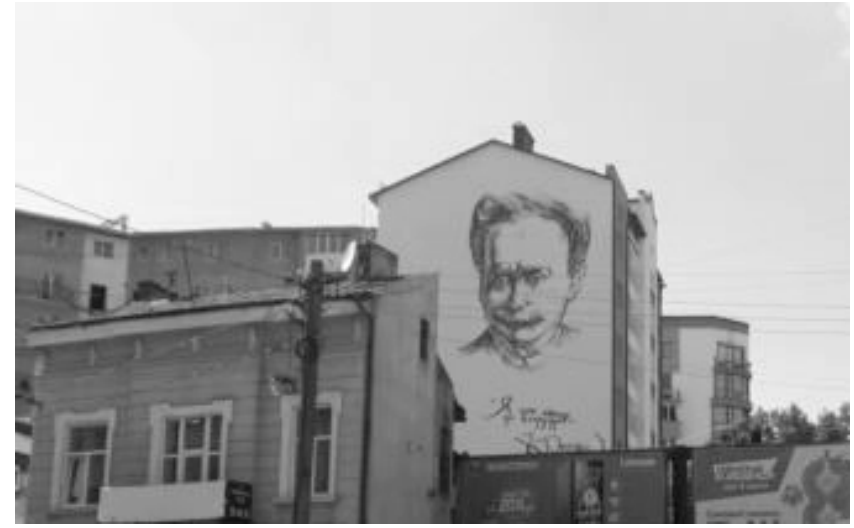

Fig.3. Mural at 19, Beljvederska str.

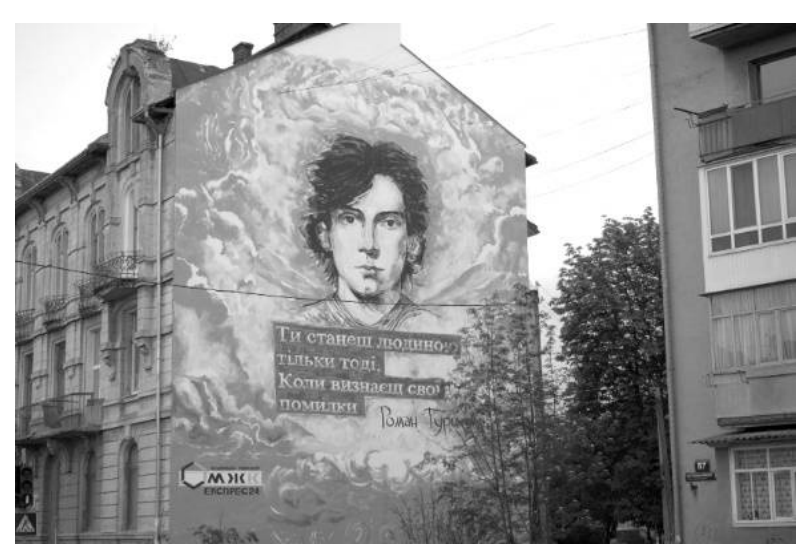

Fig.4. Mural at 83, Mazepy str. 
The appearance of conceptual murals in Ivano-Frankivsk environment is mainly due to the festivals with an urban orientation. One of the first conceptual works was introduced to the city by Argentinian graffiti artist Jorge Pomar (a.k.a. AMOR), invited in 2014 as part of the project "Frankivskyi Vulychnyi Maliunok within the framework of Teple Misto initiatives. The mural created on a facade at 2/2 Kurinnoho Chornoty str. is a color abstract diagram in which the artist sees the idea of cross-sections of our society created by a foreign observer.

In 2016, the program of the festival "PortoFranko - Gogolfest" included painting four walls in the historic part of the city, for which artists from Odessa, Lutsk, the Czech Republic and Poland were invited. The purpose of the action was an artistic and educational demonstration of progressive forms of mural painting as opposed to the traditional version of Ukrainian murals (Fig.5). The result of such an initiative was a resonance and scandal that went beyond Ivano-Frankivsk. A flurry of outraged comments from citizens, who perceived the extravagant forms of festival murals as insulting of the visual image of the city, made such a fuss on social networks and beyond, that the issue of "leave or paint over" was discussed in the regional administration office. For this purpose, a commission was set up to analyze the murals, and, as a result of discussions, it was decided not to interfere with the artistic work of the painters. 

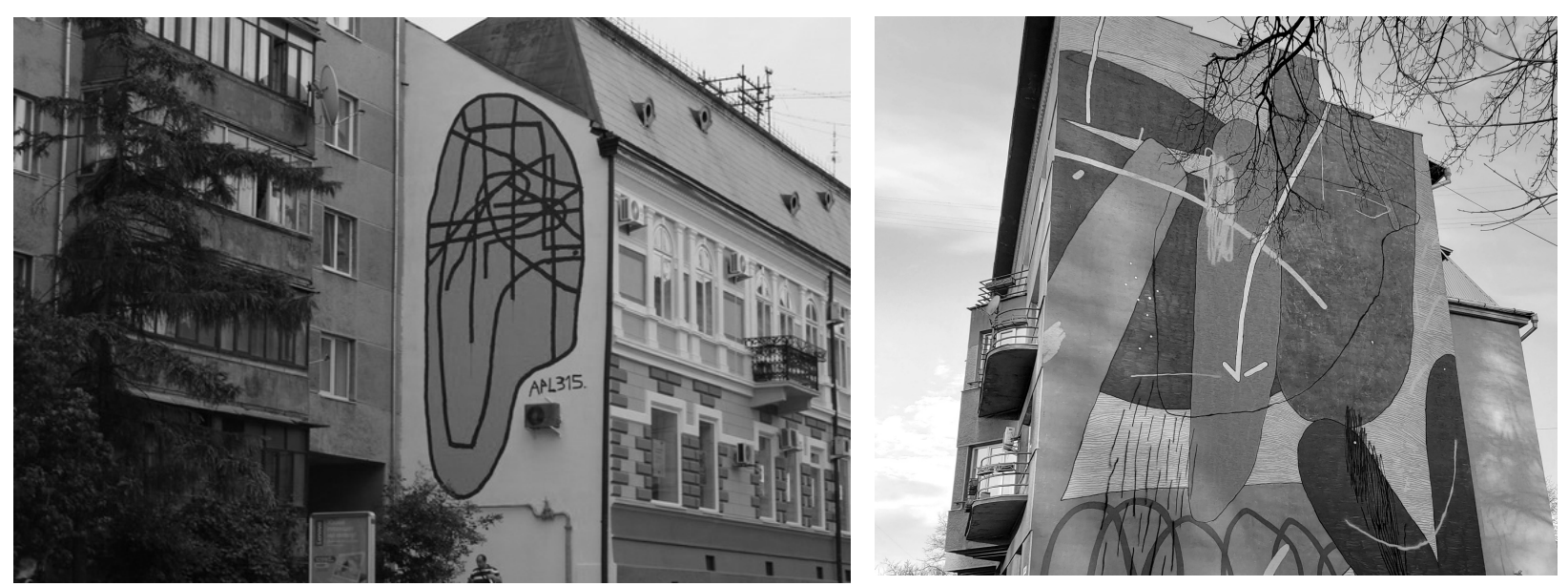

Fig.5. Examples of conceptual murals within "PortoFranko - Gogolfest" festival.

Discussions about the appropriateness of such an ambiguous artistic invasion in the urban space are subordinated to two polar world positions: one views muralism as a means of aestheticizing the environment, the other as a manifesto of critical thinking about local and global processes. While discussing the topic of conceptual Ivano-Frankivsk murals, researcher E. Molyar expressed the opinion: "In concern to the topic of contemporary art, we can state that it generally left the aesthetic domain long ago and lies rather in the domain of enlightenment. The contemplation of contemporary art is not always pleasant: on the contrary, it is a very complex and at the same time traumatic process"[4].

"Fresh Paint", a monumental work of Polish artist Sławek ZBIOK Czajkowski, was shown within the framework of Art Residence in IvanoFrankivsk. It is a mural painted on the front wall of the building at 100 , Mazepy str. (Fig.6). The main stylistic feature is the minimalist contourgraphic sketching on the white shabby wall of the building. The image depicts two stylized human silhouettes and a mirror between them. One of the figures has a distorted anatomic structure, representing a person deformed by the regimes and the second one is the Modulor, the image created by French architect Le Corbusier. The Modulor is a symbol of progress and modernization. Thus, using allegorical images, the artist 
depicts the transition from the old to the new through the process of initiation.

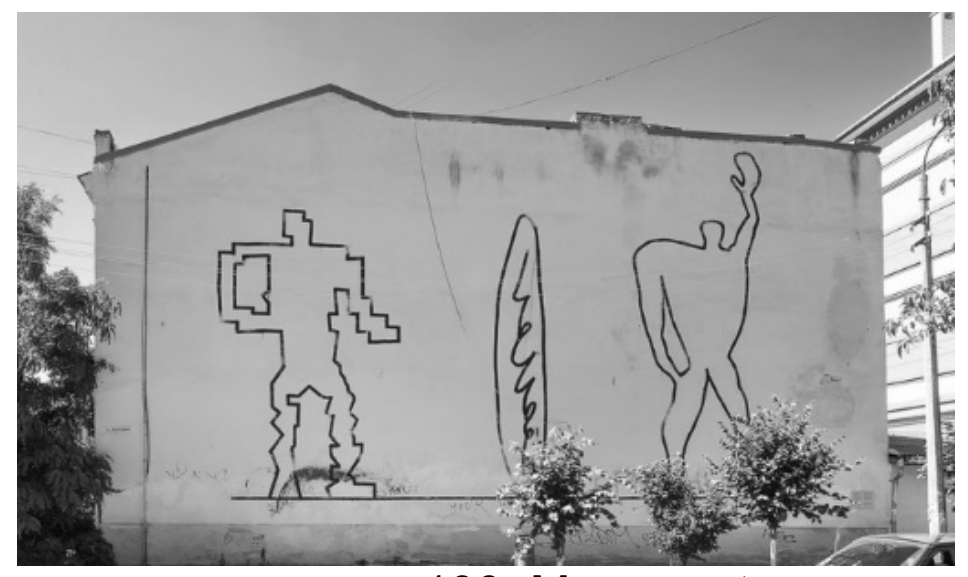

Fig.6. Mural at 100, Mazepy str.

The educational nature of the creative work was supported by an annotation board, the purpose of which was to convey the artist's ideas to the general public. Ironically, this board was destroyed almost immediately after installation.

The branch of religious murals in Ivano-Frankivsk into a separate category is prompted not only by their rapid spread in the city, but by the celebration of democratic changes in the community and the church, which begin to use postmodern practices, while broadcasting the connection with archetypal models [5, p. 22].

The first religious-themed mural was created in 2011 by J. Stetsyk "Jesus who blesses travelers" on the wall of the plant "Avtolivmash". This is a graphic replica of the popular image of "Jesus' Mercy". According to the author of the painting "We were primarily interested in Jesus, not art" [6]. However, the image, which is broadcasted by mass culture and is recognized as "kitsch", has received a conceptual meaning, being attached to current practices. So, the place of its location in the industrial zone, on the wall of the car hangar added additional content to the image - cars pass through the place where the heart of the character is localized. In addition, this facility has become a part of the annual motorcycle race, which begins 
the international art festival "Vhoru Sertsia" and where ritual practices of blessing with the participation of clergy etc.

Another precedent took place during the 2019 festival days. Artists from different cities of Ukraine in collaboration with the Ivano-Frankivsk city residents created a series of religious murals. Murals are characterized by modern figurative approaches, unusual artistic solutions, abstract compositions, fragmentary illustrative approaches. In many cases, the creation process was complemented by the practice of performance, flash mobs. Researcher E. Molyar expressed her opinion about the religious murals of the city: "The Frankivsk theme of public art differs in its bias towards sacred themes. Probably, this is how the local context manifests itself. On the one hand, it is good that art responds to local characteristics and community demand. On the other hand, the clericalization of society does not indicate its development, on the contrary " [7].

Mural at 148, Independence str., called "Miserere" or "Lord, have mercy" based on the text of the 50th psalm was performed by the artist $O$. Bazyuk at 148, Nezalezhnosti str. (Fig.7). The peculiarity of the painting is the execution of a mural on an unrestored wall, which becomes, directly, an active part of the composition in combination with the image of a wreath of thorns, which turns into a halo of holiness. Rough graphic style together with the grunge facade create an interesting visual effect. Two wall murals "Ropes of Love", located at 1, 9 Lepkoho str. were inspired by the painting with the same name by $O$. Smaga and is a reference to the texts of the prophet Hosea (Fig.8). They symbolize the salvation of mankind through God's love, the connection of people with God and each other. J. Stetsyk, V. Novy, V. Pernerovsky became the performers of the painting. The mural depicts pierced palms, made in a rough graphic manner, based on the iconpainting canon. Geometric lines are stretched from the wounds along the 
entire plane of the facade, which is the embodiment of "ropes" and a symbol of the blood of Christ.

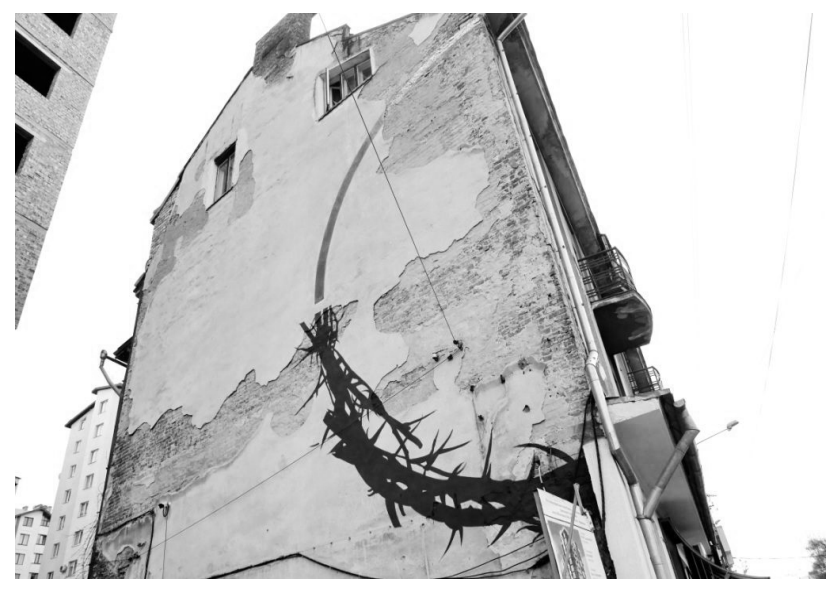

Fig.7. Mural at 148, Nezalezhnosti str.

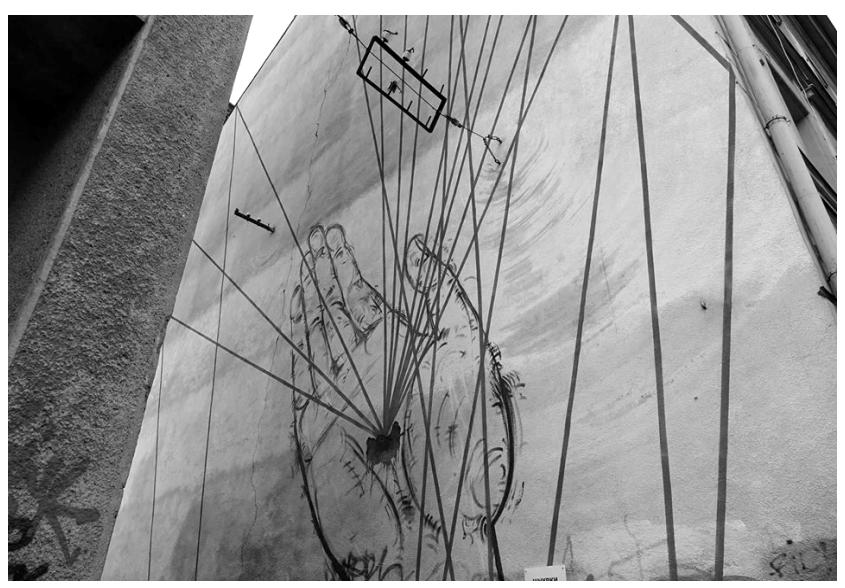

Fig.8. Mural at 9, Lepkoho str.

The mural "Cherubim" by D. Movchan (Lviv) is a geometrized stylization, known from Greek and Byzantine iconography, created by using local blue and red. This symbolic motif of the Divine presence has decorated the facade of the building at 16, Lepkoho str. Another mural at 32, Shevchenko str. was a continuation of the project "Vohni Sviatoho Duha", within which all willing residents of the city had the opportunity to depict their own graphic version of the fire on plywood, which was later exhibited at the Potocki Palace. The decisive stage of the process was the transfer of these images to the facade of the building (Fig. 9). Thus, the city community was able to make a direct contribution to the creation of the mural. The result is a dynamic abstract composition in pure local colors. 


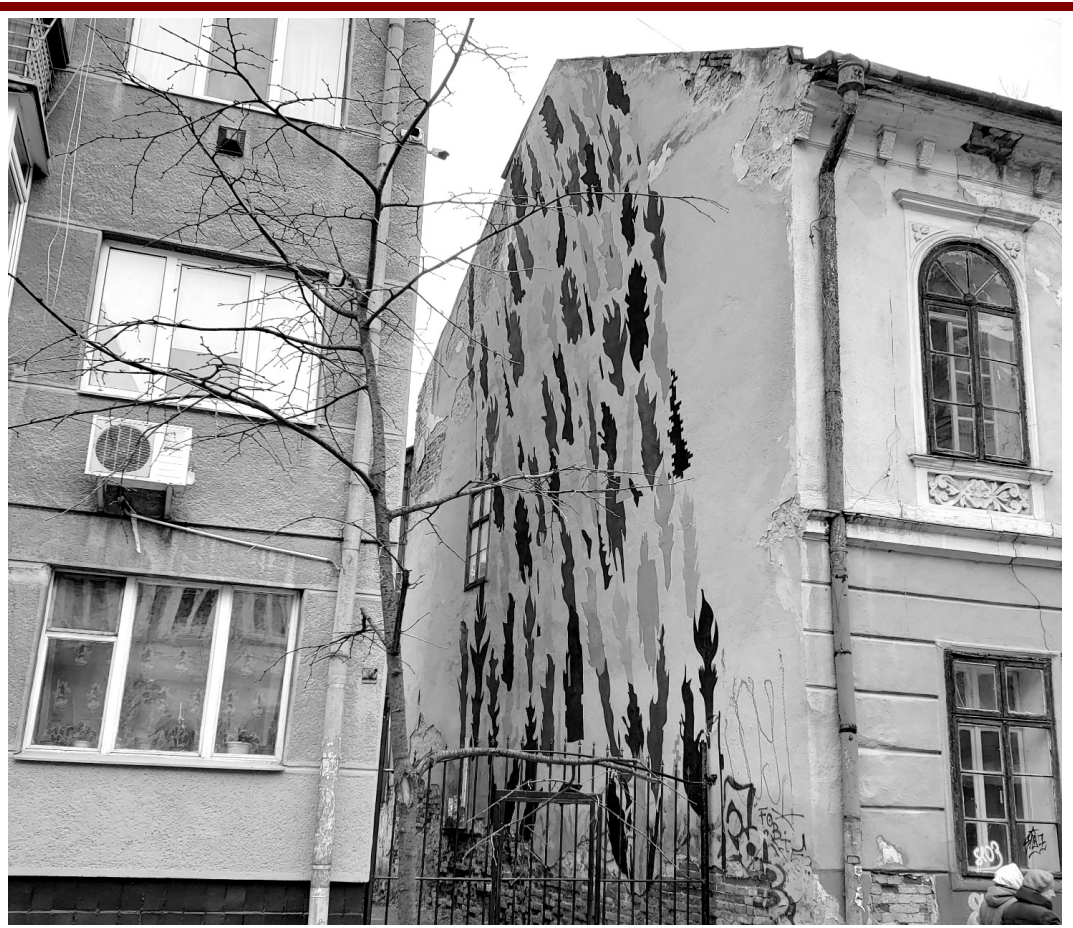

Fig.9. Mural at 32, Shevchenko str.

Conclusion. As a result of analysis on stylistic characteristics and ideological bases of murals in Ivano-Frankivsk city, we conclude that muralists operate mainly with the expressiveness of graphic images, highlighting favorite styles or combining realism, photographic characteristics and collages of pop art, surrealism, combinatorics, primitivism etc. So, it seems that the art of muralism belongs to the spectacular topical practices that have no stylistic limitations. It should also be noted that murals often characterize collective creativity, where the author's idea is transformed through the performing arts and connection with the environment or society, thus demonstrating the "death of the author", which is also a characteristic trait of postmodern practices.

\section{References:}

1. lefimova A. (2014) Peculiarities of realization the actual tendencies of art in urban spaces in Western Ukraine: modern monumental art practices. Ukrainska kultura: mynule, suchasne, shliakhy rozvytku. Naukovi zapysky RDHU, 20 (1), 286-291. [in Ukrainian].

2. Kolisnyk O. V., Ponomarova N. S. (2019) Murals as a means of social communication. Comparison of world experience. Kyivskyi natsionalnyi 
universytet tekhnolohii ta dyzainu Art and Design, no 2, 62-73. [in Ukrainian].

3. Zvizhynskyi A. (2016) Walls and murals. The old design. Retrieved from: https://zbruc.eu/node/60519 [in Ukrainian]. (2020, December, 25).

4. Chudnenko K. (2016) Mural and people. Artmisto. Retrieved from: http://artmisto.net/2016/10/30/mural-i-misto/ [in Ukrainian]. (2020, December, 25).

5. Babii N. (2020) Secularization of current artistic practices of Western Ukraine in the XXI century. Mystetska kultura: istoriia, teoriia, metodolohiia : tezy dopovidei VIII nauk. konf. Lviv, 22-24.

6. Deichakivska S. (2015) Frankivsk Street Art: who and why paints on city walls, vol. 2. Retrieved from: http://ufra.com.ua/mistsia/365-streetart2.html [in Ukrainian]. (2020, December, 25).

7. Perekhrest O. (2019) Frankivsk murals: who paints them, why and where to look. Retrieved from:https://kufer.media/misto/muraly-frankivska/ [in Ukrainian]. (2020, December, 25).

Citation: S. Chuchuk (2020). STYLISTIC FEATURES AND IDEOLOGICAL CODES OF MODERN URBAN MURALS: THE CASE OF IVANO-FRANKIVSK CITY. Frankfurt. TK Meganom LLC. Paradigm of knowledge. 6(44). doi: 10.26886/2520-7474.6(44)2020.7

Copyright S. Chuchuk ( $)$. 2020. This is an openaccess article distributed under the terms of the Creative Commons Attribution License (CC BY). The use, distribution or reproduction in other forums is permitted, provided the original author(s) or licensor are credited and that the original publication in this journal is cited, in accordance with accepted academic practice. No use, distribution or reproduction is permitted which does not comply with these terms. 